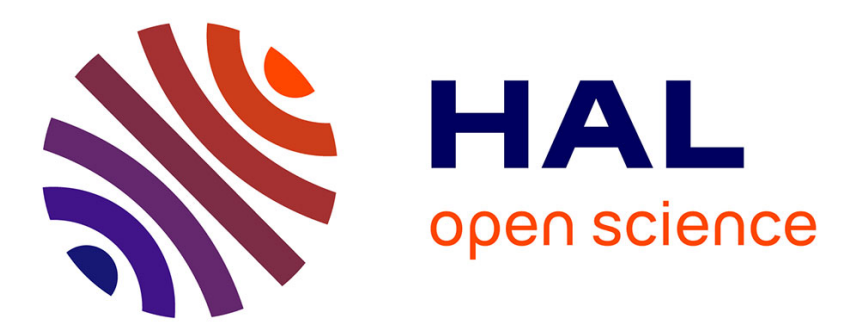

\title{
Confronting coastal morphodynamics with counter-erosion engineering: the emblematic case of Wissant Bay, Dover Strait
}

\author{
Mouncef Sedrati, Edward J. Anthony
}

\section{- To cite this version:}

Mouncef Sedrati, Edward J. Anthony. Confronting coastal morphodynamics with counter-erosion engineering: the emblematic case of Wissant Bay, Dover Strait. Journal of Coastal Conservation: planning and management, 2014, 18 (5), pp.483-494. 10.1007/s11852-013-0300-1 . insu-01100760

\section{HAL Id: insu-01100760 \\ https://hal-insu.archives-ouvertes.fr/insu-01100760}

Submitted on 8 Jan 2015

HAL is a multi-disciplinary open access archive for the deposit and dissemination of scientific research documents, whether they are published or not. The documents may come from teaching and research institutions in France or abroad, or from public or private research centers.
L'archive ouverte pluridisciplinaire HAL, est destinée au dépôt et à la diffusion de documents scientifiques de niveau recherche, publiés ou non, émanant des établissements d'enseignement et de recherche français ou étrangers, des laboratoires publics ou privés. 
Confronting coastal morphodynamics with counter-erosion engineering: The emblematic case of Wissant Bay, Dover Strait.

Mouncef Sedrati ${ }^{1}$, Edward J. Anthony ${ }^{2}$

${ }^{1}$ Université de Bretagne-Sud, Equipe Géosciences Marines \& Géomorphologie du Littoral, LDO - UMR 6538, Campus de Tohannic, Centre de Recherche Yves Coppens, BP 573, 56017 Vannes cedex, France. mouncef.sedrati@univ-ubs.fr

${ }^{2}$ Aix Marseille Univ, Institut Universitaire de France, CEREGE, UMR 34, Europôle Méditerranéen de l'Arbois, B.P. 80, 13545 Aix en Provence, France. anthony@cerege.fr 


\title{
Confronting coastal morphodynamics with counter-erosion engineering: The emblematic case of Wissant Bay, Dover Strait.
}

\begin{abstract}
Wissant Bay is a picturesque and highly frequented French coastal resort comprising beaches, dunes, marshes, and bold capes facing the Dover Strait. Situated at the southern approaches to the North Sea, the $8 \mathrm{~km}$-long bay has, arguably, the most rapidly eroding shoreline in metropolitan France. Retreat has largely affected much of the bay shoreline west of Wissant town, with parts of this sector having lost up to $250 \mathrm{~m}$ in the last fifty years, whereas a much smaller sector east of the town is a zone of accretion. Various dune, beach and nearshore morphodynamic studies conducted over the last decade have identified chronic sand bleeding from the western sector and longshore transport to the east, within a framework of what appears to be an ongoing shoreline rotation process within a dominant longshore sediment transport cell between the headland of Cape Gris Nez to the west and the bold chalk cliffs of Cape Blanc Nez to the east. Retreat of the narrowing beach-dune barrier poses a threat in the coming years, as there is a likelihood of it being breached by storms. The seawall protecting Wissant town has also been repeatedly damaged since 2000 due to the chronic sand deficit. These changes involve interactions between a nearshore sand bank, a complex macrotidal beach comprising multiple subtidal to intertidal bars and troughs subject to strong longshore sand transport especially during storms, and aeolian dunes. The nearshore bank acts as a dissipater of incident storm wave energy and as a sand source for the multi-barred beaches and dunes, and has been strongly impacted by past massive aggregate extraction. The bank is, in turn, part of a larger system of mobile banks reworked by storms and tidal currents within the framework of a sand circulation system between the eastern English Channel and the southern North Sea. The aim of this work is to confront knowledge acquired on the morphodynamics of the bay with an engineering plan proposed to counter erosion and reestablish shoreline stability. The plan is based essentially on the creation of an 'equilibrium' beach profile, capable of withstanding storms, comprising an enlarged upper beach berm, and constructed through beach nourishment from a nearshore source located $20 \mathrm{~km}$ east of Wissant Bay. The plan has not been implemented because of cost. Even if it were to be implemented, its efficiency seems very doubtful because the beach profile simulations on which it is based neglect the complex multi-barred morphology and the overwhelming dominant longshore transport over bars during storms. The plan is also geared towards resolving a local problem of erosion that is embedded in the larger and rather complex spatiotemporal morphodynamics and sediment transport mechanisms evoked above. Wissant Bay is emblematic of the problems of erosion facing many communes in France, and elsewhere. The fight against shoreline erosion generally starts with the commonly insurmountable hurdle of fund-raising for costly engineering proposals that are not always based on a clear grasp of the embedded scales of change affecting the coast.
\end{abstract}

Keywords: Coastal erosion, coastal engineering, coastal morphodynamics, macrotidal coast, beach nourishment, beach rotation, Wissant Bay. 


\section{Introduction}

One reason for the failure of many operations aimed at countering shoreline erosion is that their conception and implementation are commonly not based on a sufficient knowledge of processes shaping the coast at various morphodynamic scales. In many situations, the links between short- to long-term geomorphic change in small segments of coast and the way these are embedded in, and controlled by, larger-scale aspects of coastal change, are not always well apprehended (Gelfenbaum and Kaminsky, 2010). From a coastal management point of view, a first step towards a better understanding of this scale relationship has been the coastal cell concept, commonly used in a sediment budgetary framework in which process gradients may or may not be ignored, the emphasis being on definition of each coastal cell and on the net gains and losses of sediment within each cell (e.g., Bray et al., 1995; Cooper and Pontee, 2006; Patsch and Griggs, 2008; Anfuso et al., 2011; van Rijn, 2011). This is a useful approach but even where coastal cell definition may appear simple, the task of simply delineating the shoreline and constraining the processes operating both across shore and alongshore in such cells may turn out to be difficult (Kaminsky et al., 2010). In particular, the sediment dynamics of alluvial coasts subject to large tidal ranges can be quite complex because of potentially strong tidal currents, modulation of wave action by tides, and large variations in the 'shoreline' controlled by tidal range. This situation can be even more so where large stocks of loose mobile sediments are available and constantly reworked by processes generated by waves and currents over large shorefaces, as in the English Channel, the southern North Sea and some of the marginal seas in Asia. The ensuing morphodynamic adjustments between such sediment stocks and the forcing agents can lead to particularly complex situations where sediment cells are hard to define and where apprehension of coastal change requires crossing short- to long-term series of observations at various spatial and temporal scales. In such situations, sound solutions to problems of local coastal erosion require taking into account the complex, larger-scale morphodynamic background.

These issues are examined here using the example of Wissant Bay, a highly frequented resort in the Dover Strait (Fig. 1a), set in a particularly complex environment in terms of coastal processes. The bay shoreline has varied significantly over the last half century, with certain sectors, hitherto prograding, now in a particularly critical condition in terms of erosion. A detailed plan has been set up for the implementation of engineering solutions. Meanwhile, numerous studies conducted over the last decade have progressively highlighted the complex patterns of shoreface and shoreline change at both the small-scale level of the Wissant town front, where erosion poses a direct hazard, and at the larger bay scale. This larger scale is embedded in the hydrodynamic and sediment circulation system of the Dover Strait. In this paper, we will briefly summarise the recent findings on the morphodynamics of the bay, confront these with the proposed engineering solutions, and then discuss why Wissant Bay is emblematic of many communes, in France, and elsewhere, where the fight against erosion is commonly stalled by fund-raising for costly engineering proposals that are not always based on a clear understanding of the embedded scales of change affecting coasts.

\section{Wissant Bay}

Beach, dune and shoreface morphology

Wissant Bay is, in terms of setting and morphological diversity, commonly considered as one the most picturesque sites on the southern North Sea coast, occupying an $8 \mathrm{~km}$-long mild embayment between bedrock cliffs. Wissant town has functioned as a resort since the 19th century. It is extremely popular, and its beaches, dunes, marshes, and bold capes facing the Dover Strait offer a variety of tourism-based recreation and leisure activities. The bay is also part of a protected site. The dunes in Wissant Bay form a linear barrier 100 to $300 \mathrm{~m}$ wide and 
with a maximum inland height of about $20 \mathrm{~m}$. They impound marshes of ecological value.

\section{Hydrodynamic context}

Wissant Bay lies in a typical mixed storm-wave- and tide-dominated environment subject to a complex pattern of time-varying influences of tides and storms, in addition to wind-forced flows (Héquette et al., 2008). Winds are dominantly from southwest and northeast, but the strongest winds mostly originate from west to southwest. The hydrodynamic context is that of a short-fetch, storm-wave environment, characterised by marked short-term (order of days to weeks) fluctuations in wave height (Fig. 2a). The dominant waves are from southwest to west, originating from the English Channel, followed by waves from the northeast to north, generated in the North Sea. Breaking waves are essentially from a north-northeast to northwest window, although the dominant deepwater directions are from both north and west. The tidal regime in the region is semi-diurnal and macrotidal, the tidal range in Wissant Bay being about $6.5 \mathrm{~m}$ during spring tides. In calm weather, current directions are closely conditioned by the tide, with dominantly longshore eastward-directed flood directions and westward ebb directions (Fig. 2b). Strong winds enhance ebb or flood current speeds when blowing in the same direction, or limit, and even prevent tidal reversal when blowing in the opposite direction in the bay (Sedrati, 2006), but flow is more commonly flood-dominated. During conditions of significant wind stress (sustained wind speeds $>10 \mathrm{~m} . \mathrm{s}^{-1}$ ), the peak current speeds can be two to three times higher than 'normal' (tide-generated) peak spring tide speeds $\left(\sim 0.45 \mathrm{~m} . \mathrm{s}^{-1}\right)$. Longshore currents, especially setting east, can become particularly strong during storms as a result of direct wind stress (Sedrati and Anthony, 2007) and reinforcement by longshore gradients in radiation stress that divert, alongshore, offshore mean 
currents generated as waves pass over or break over the sand banks (Anthony, 2013). Storms may add up to $1 \mathrm{~m}$ of surge above high-tide swash excursion levels.

\section{Morphodynamic sectors}

Wissant Bay comprises three sectors (Fig. 1b): a 6 km-long strongly eroding western sector, comprising Dune du Châtelet and Dune d'Aval, where the foredune has retreated by up to 250 $\mathrm{m}$ between 1949 and 2000 (Fig. 3), following an early period of stability and even progradation (Aernouts and Héquette, 2006; Chaverot et al., 2008), a short central sector, Wissant town, fronted by a seawall that has held the shoreline, and an equally short accreting eastern sector, Dune d'Amont. Sedrati and Anthony (2008) showed that a retreat rate of the dune front of up to $4 \mathrm{~m}$ in the eroding western sector can occur in just 24 hours during severe storms associated with high surge levels (up to $1 \mathrm{~m}$ ) and high spring tides. This value is equivalent to the annual mean shoreline retreat rate calculated for the Dune d'Aval sector by Aernouts and Héquette (2006). This suggests a highly rhythmic foredune retreat that depends on the right combination of storm waves, spring tidal range and storm surge conditions. This erosion has led to the cropping out of peat on the beach representing former backbarrier vegetation. Erosional in the past, the eastern sector of the bay is now a zone of deposition, characterised by significant foredune growth and active formation of embryo dunes (Anthony et al., 2006). In terms of the overall shoreline dynamics, the western and central parts of the bay constitute a long updrift erosional sector linked to a short downdrift depositional sector in the east.

Figure 4 shows unpublished beach profiles that summarise these three sectors. The first and the last of these three profiles start from the dune front. The Wissant profile starts from the seawall protecting the town. The Dune d'Aval profiles show a typical system of bars and troughs the changes of which reflect both cross-shore beach mobility and longshore bar mobility. Two significant aspects associated with the profile changes at this site are the low elevation of the beach close to the dune front and the marked retreat of the latter (Fig. 4a). At a distance of 100 $\mathrm{m}$ from the survey origin point, the beach profile fluctuations occur within an envelope of nearly 4.5 below the high water neap tide level. The dune front shows nearly monotonous retreat over the survey period, exceeding $20 \mathrm{~m}$. The Wissant townfront profile shows much larger fluctuations than the previous profile (Fig. 4b). The bar and trough morphology is, consequently, much more pronounced. At a distance of $100 \mathrm{~m}$ from the survey point on the seawall, the beach fluctuations are up to $4.5 \mathrm{~m}$ below the level of high neap tides. The envelope of fluctuations at the foot of the seawall attained up to $3 \mathrm{~m}$ during the survey period. The Dune d'Amont profile shows a system of more subdued bars with a milder envelope of fluctuation (Fig. 4c). The envelope below the mean high water neap tide level within the $100 \mathrm{~m}$ distance is about $2 \mathrm{~m}$.

The net sand budget changes of the three profiles over the survey period are depicted in Fig. 5 . Dune d'Aval and Wissant town front show a fluctuating but strongly negative sand budget over much of the survey period, whereas Dune d'Amont beach shows a fluctuating but net positive budget with a single negative value in 1998. The three profiles in Wissant Bay show envelope patterns and net budget changes that reflect the west to east gradient in shoreline mobility highlighted by Chaverot et al. (2008). The profile of the beach in the eroding western sector of the bay is significantly lower than in the accreting sector in the east. This difference in elevation also goes with much larger bar and trough fluctuations in the eroding sector, which clearly incorporates Wissant town front. Photographs of the town front shoreline in 1952 and 1986 show a much more accreted beach with sand covering the seawall, which is clearly visible in the earlier 1909 photograph (Fig. 6a). This suggests that sand was still accumulating in this central sector nearly 30 years ago, a situation that contrasts with the beach lowering and repeated damage to the seawall since 2000 (Fig. 6d-f). 


\section{Proposed management solutions to erosion}

The investigations summarised above have thrown light on the large-scale processes involved in sediment movements in which are embedded shorter-term changes such as those depicted by the beach profiles (Fig. 4). To summarise these findings, we note active sand transfer over the shoreface of the bay from west to east within at least the last three decades, resulting in sustained erosion of the western bay foredunes and lowering of the beach. The retreat constitutes a threat in the coming years, because of the likelihood of storm breaching of the narrowing dune barrier. In essence, this entails eventual failure of the retreating dune front in the west, leading to marine invasion of a backbarrier marsh (Fig. 1b) of high ecological value. Wissant town is also becoming increasingly vulnerable to submersion.

At the scale of the entire bay shoreline, the only sector where efforts at containing erosion have been deployed is the town front with its seawall. Figure 6a shows an inclined seawall in 1906 that served as a coastal defence structure in replacement of the mobile dunes and as a seafront promenade as the town prospered essentially from winter tourism. The wall assumed a military defence function during World War 2 when the Atlantic Wall was built along large parts of the French coast, including Wissant Bay, by the German army. Much of this Atlantic wall has been eroded. Remnants still subsist on the beach in the western sector, whereas remnants in the eastern accreting sector have been largely buried by aeolian dune accretion. Since 2000, the seawall fronting the town has been damaged on several occasions by storms, and undermined by beach lowering at its base (Fig. 6d-f). The difference in profile morphology between Dune d'Aval and Wissant town (Fig. 4) appears to reside essentially in the presence of this seawall, which has acted as a rampart against shoreline retreat, notwithstanding the progressive beach lowering. Hence the exclusion of this sector (Fig. 3) from the multi-decadal shoreline mobility survey conducted by Chaverot et al. (2008).

The fight against erosion in Wissant Bay has been mainly focussed on maintaining the seawall. Damages have been repaired in piecemeal fashion following severe storm attacks (Fig. 6), as the wave of erosion, largely ignored as long as it concerned only the uninhabited Dune du Châtelet and Dune d'Aval sector, started affecting the town front more actively. Wissant Bay is a protected site of natural value, and this drastically reduces the possibility of implementing heavy defence structures such as breakwaters and concrete or rock groynes. The installation of a low-cost but more ecologically 'friendly' defence system of wooden dykes was envisaged but rapidly abandoned by the communal authorities because it was viewed as nefarious to tourism and recreation. The most comprehensive management options have been proposed by CETMEF (2004), a state-run agency in fluvial and coastal engineering expertise, and by SOGREAH (2006), a private hydraulic engineering firm. In a global study that recommended beach nourishment as the primary solution, CETMEF (2004) stipulated that a policy of "no intervention' constituted a threat to the commune. This report also recongnised the limited utility of reinforcing the seawall by emplacing rock armouring because of the rampant erosion and the high cost of this defence option, as well as the relatively low potential efficiency of wooden groynes, and the problems such structures will pose for various beach activities such as kiting, kite-surfing, sand yachting and speed sailing. CETEMEF (2004) proposed sand nourishment over a distance of $2.5 \mathrm{~km}$ covering the central sector (Wissant town front) and extending $200 \mathrm{~m}$ west of the seawall. This solution was subsequently also retained by SOGREAH (2006). Much of the expertise proposed was based on defining an 'equilibrium' beach profile to be attained through nourishment using a variant of the SBEACH (Storminduced BEAch Change) Model of the US Army Corps of Engineers (Larson and Kraus, 1989; Rosati et al., 1993) that simulates cross-shore beach, berm, and dune erosion produced by storm waves and high water levels. SOGREAH (2006) proposed an initial renourishment to the 
tune of $300,000 \mathrm{~m}^{3}$ in order to rebuild the upper beach lowered by erosion and to attain this equilibrium profile, and examined the possibility of the adjunction of groynes to hold the recharged sand against drift to the east, but this latter proposal was discarded on the grounds evoked above. An alternative solution of complementary annual nourishment to the tune of $15,000 \mathrm{~m}^{3}$ was thus proposed. Another complementary option consisted in installing a beach drainage system using the Ecoplage ${ }^{\circledR}$ procedure to help maintain recharged sand. The nourishment project also recommended the dismantling of the last blockhouses subsisting as part of the Atlantic seawall, and dune rehabilitation in the eroding Dune d'Aval sector. The estimated cost of these operations ranged from 6.2 to $9.05 \mathrm{M} €$, depending on optional adjunctions, maintenance and annual sand recharge over 20 years. The plan also highlighted the numerous risks of failure and uncertainties related to the operations proposed.

Discussion: confronting engineering options with processes and scales of shoreline change Wissant Bay is an emblematic example of the problems facing many coastal communes in France wherein several layers of difficulties have resulted in stalted shoreline protection and in failure in the fight against erosion. A major problem, which is the focus of this paper, is that of confronting such solutions with morphodynamics of the coast at various scales. Confronting management options with the processes and scales involved in shoreline change is often a major challenge. This is particularly well illustrated in Wissant Bay, arguably the most strongly eroding coast in metropolitan France. The engineering solutions proposed to stave off erosion in Wissant Bay do not sufficiently take into account the complexity of the sediment dynamics of the bay. This large tidal-range setting is subject to important tide-, wind- and storm-wave-controlled fluxes that are embedded in a larger-scale sediment circulation system between the eastern English Channel and the North Sea. The shoreline rehabilitation plan proposed by SOGREAH (2006) is strongly centred around simulations of an equilibrium beach profile (corresponding essentially to the Wissant town front sector (Fig. 4b)) that includes the construction, via beach nourishment, of an enlarged berm, in front of the failing seawall, capable of withstanding storm attack, and the stability of which will be further enhanced by the Ecoplage operation. However, the maintenance of a complex multi-barred profile of the beach in Wissant Bay is not considered in these simulations which are indeed unlikely to adequately replicate such complex beach morphology. Storm wave dissipation is assured by: (1) the Line Bank offshore, (2) inshore by the multiple subtidal to intertidal bars, and (3) the aeolian foredune front, and not just by an enlarged beach berm and upper beach drainage. Furthermore the main beach morphodynamic process during such storms is strongly hinged on longshore sand transport over the bars, rather than on offshore sand losses. Figure 7 shows unpublished calculated sand transport rates over the multi-barred beach using the formulation by van Rijn (1990), based on wave and current data acquired in 2005 (Sedrati, 2006). The results highlight the overwhelming importance of longshore transport relative to cross-shore transport. Sedrati and Anthony (2007) showed from high-resolution beach topographic changes that these longshore transport conditions are considerably reinforced during storms. Anthony (2013) has recently suggested that this longshore transport may be reinforced by longshore gradients in radiation stress generated by $3 \mathrm{D}$ changes in the morphology of the Line Bank from west to east. These gradients divert offshore storm flows alongshore, hence preventing sand loss offshore but strengthening sand transfers from west to east.

The large-scale interactions encompassing the Line Bank offshore clearly illustrate here the difficulty, predicted by Sipka (1997), of using the cell concept as a management tool on the macrotidal coasts of the Dover Strait and the southern North Sea where cell boundaries are hard to delimit both alongshore and seaward. It seems very likely that the progressive erosion affecting Wissant Bay is part of the long-term (multidecadal) shoreline response to the 
lowering of the Line Bank, diminishing both its capacity to dissipate storm waves and to supply sand to the beaches and foredunes in the west. As lowering of the Line Bank has occurred, storm wave energy dissipation has been largely transferred to the bar-trough beach and the foredune front, notably in the deeper western sector. Aernouts and Héquette (2006) showed from a SWAN wave propagation model simulation that incident wave energy over the bank had increased in 2002 relative to 1977 due to the lower bank surface. The beach and dunes adjacent to the deeper western end of the bank have, therefore, been rapidly retreating. Although the thrust of the anti-erosion plan proposed by SOGREAH (2006) is on cross-shore dissipation of storm wave energy, the plan does recognise the need to contain longshore sand transport but only via a short-term (with costs exponentially increasing from five to 20 years) renourishment plan. There is no vision of what may happen beyond this period. The past changes in shoreline retreat and advance that have affected Wissant Bay have been viewed in terms of a multidecadal to secular shoreline rotation process (Sedrati and Anthony, 2008). There appears to be little scope for reversal of this sand transfer process in the future, given the effectively strong large-scale residual drift to the east. Rotation is generally reversible, but also operational on shorter timescales of seasons (e.g., Norcross et al., 2002; Jeanson et al., 2013) to years (Thomas et al., 2012). The strong drift to the east that reinforces the destabilisation of the western sector of the bay is also due to combined wave, tide and wind-induced currents, thus differentiating the Wissant Bay system from many of the beach rotation examples described in the literature, driven by changes in combined incident wave energy and direction. Since one of the two trailing edges of the Line Bank is close inshore in the Dune d'Amont sector, it probably provides sand for the coastal dunes and shelters the shore from the larger storm waves. The loss of sand by this bank and the scale of longshore sand transfer to the east may suggest that even an expensive long-term renourishment solution based on constant truckload transfers to the western beach sector of sand accumulating feeding foredune accretion in the east may not be tenable in terms of cost, nor given the ecological status of the bay dunes. Without a consideration of the rehabilitation or renourishment of the Line Bank sand source and wave energy dissipater, such a renourishment solution may also not be enough to counter the progressive retreat of the dunes in the west of the bay. The anti-erosion and rehabilitation plan proposed by SOGREAH (2006) does not concern aeolian dune rehabilitation in the eroding western sector.

Two other problems facing the fight against erosion in Wissant Bay are a clear definition of responsibilities in coastal management and in the implementation of engineering solutions against erosion, and finding funds to finance such engineering solutions. Lobbying against erosion has been spearheaded by the landowners' association in Wissant Bay. A French law of 1807 stipulated the setting up of landowner associations that had to bear, proportionately to the interests of each landowner, all costs of defence or maintenance works carried out on the shore or along river banks. Exceptions concerned sectors where government interests were concerned, thereby providing a source of state subsidy for such works. Enforcement of this law was never really assured and under the continuing pressure of coastal urbanisation, generally spurred on by large-scale lucrative estate acquisition and development, the state decided, in the Law of 1973, to allow individual communes or unions of communes to undertake coastal defence works where this was deemed necessary to preserve the common interest. This is presently the situation in France, where the municipality or commune bears the costs of local defence operations, with the possibility of additional funding by the Regional Council. Authorisations concerning the implementation of defence works on urbanised coasts, and decisions as to whether state funding is appropriate, are taken by a regional engineer delegate of the state directorate responsible jointly for matters of environment, territorial management, and housing. State funding is exceptional. The problem is compounded in Wissant Bay by the high costs involved in even implementing a plan such as that proposed by SOGREAH (2006). 
van Rijn (2011) indicated as an acceptable cost a range of 100-150 $€$ per metre of coast per year over a 20 -year period for $100 \mathrm{~km}$ of the Holland coast, a country where the fight against coastal erosion is as much a tradition as a national priority. The cost of the proposed Wissant Bay plan is $125-362 €$ per metre of coast over a 20 year period depending on options and effective maintenance operations, a cost well beyond the possibilities of the commune. Effective implementation of the plan has been delayed by lack of funds and it is doubtful whether the plan will be ever implemented. Hence the continuing erosion and the piecemeal repairs to the seawall.

\section{Conclusion}

The case of Wissant Bay illustrates a common situation in France, and in many other countries, where problems of shoreline defence and rehabilitation are considered in a short-term, piecemeal perspective that is often hinged on local problems that are not viewed within the larger context of spatiotemporal shoreline change and the processes involved. In France, there has generally been lacking an overall view of management practice in terms, for instance, of coastal sediment cells, although this situation has been changing in the last few years. As a result, the spread of beach erosion has commonly been aggravated by individual communal efforts lacking a common view of what exactly is happening, and the effects on downdrift sectors, of engineering structures implanted in updrift sectors. The problem has been exacerbated by the high costs involved in implementing a plan against erosion. The implementation of the anti-erosion operations proposed by SOGREAH (2006) has been delayed by lack of funds and it is doubtful whether these operations will ever see the light of day. Should one conclude from this that the cost of defending Wissant is too high relative to the value of the resort? This raises the delicate issue of considering other management options such as set-back lines (e.g., Ferreira et al., 2006), options that may not be readily accepted by the communal authorities of Wissant.

\section{Acknowledgements}

We thank three anonymous reviewers and Norbert Psuty for their salient suggestions for improvement.

\section{References}

Aernouts, D., Héquette, A., 2006. L'évolution du rivage et des petits fonds en Baie de Wissant pendant le XXè siècle, Pas-de-Calais, France. Géomorphologie : relief, processus et environnement, 1, 49-64.

Anfuso, G., Pranzini, E., Vitale, G., 2011. An integrated approach to coastal erosion problems in northern Tuscany (Italy): Littoral morphological evolution and cell distribution. Geomorphology, 129, 204-214.

Anthony, E.J., 2013. Storms, shoreface morphodynamics, sand supply, and the accretion and erosion of coastal dune barriers in the southern North Sea. Geomorphology, 199, 8-21.

Anthony, E.J., Mrani Alaoui, M., Héquette, A., 2010. Shoreface sand supply and mid- to late Holocene aeolian dune formation on the storm-dominated macrotidal coast of the southern North Sea. Marine Geology, 276, 100-104.

Anthony, E.J., Vanhée, S., Ruz, M.H., 2006. Short-term beach-dune sand budgets on the North Sea coast of France: sand supply from shoreface to dunes and the role of wind and fetch. Geomorphology, 81, 316-329. 
Anthony, E.J., Vanhée, S., Ruz, M.H., 2007. Embryo dune development on a large actively accreting macrotidal beach: Calais, North Sea coast of France. Earth Surface Processes and Landforms, 32, 631-636.

Bray MJ, Carter DJ, Hooke JM., 1995. Littoral cell definition and budgets for central southern England. Journal of Coastal Research, 11, 381-400.

CETMEF, 2004. Approche qualitative du fonctionnement hydrosédimentaire de la baie de Wissant et son application pour la définition de solutions. Rapport du Centre d'études techniques maritimes et fluviales. Ministère de l'Equipement, des Transports, du Logement, du Tourisme et de la Mer. $72 \mathrm{p}$.

Chaverot, S., Héquette, A., Cohen, O., 2008. Changes in storminess and shoreline evolution along the northern coast of France during the second half of the 20th century. Zeitschrift für Geomorphologie 52, Suppl. 3, 1-20.

Cooper, N.J., Pontee, N.I., 2006. Appraisal and evolution of the littoral 'sediment cell' concept in applied coastal management: Experiences from England and Wales. Ocean \& Coastal Management, 49, 498-510.

Ferreira, O., Garcia, T., Matias, A., Taborda, R., Alveirinho Dias, J., 2006. An integrated method for the determination of set-back lines for coastal erosion hazards on sandy shores. Continental Shelf Research, 26, 1034-1044.

Gelfenbaum, G., Kaminsky, G.M., 2010. Large-scale coastal change in the Columbia River littoral cell: An overview. Marine Geology, 273, 1-10.

Héquette, A., Aernouts, D., 2010. The influence of nearshore sand bank dynamics on shoreline evolution in a macrotidal coastal environment, Calais, Northern France. Continental Shelf Research, 30, 1349-1361.

Héquette, A., Hemdane, Y., Anthony, E.J., 2008. Sediment transport under wave and current combined flows on a tide-dominated shoreface, northern coast of France. Marine Geology, 249, 226-242.

Jeanson, M., Anthony, E.J., Dolique, F., Aubry, A., 2013. Wave characteristics and the morphology of pocket beaches fronted by a coral reef-lagoon system, Mayotte Island, Indian Ocean. Geomorphology, 182, 190-209.

Larson, M., Kraus, N. C. (1989). Sbeach: Numerical model for simulating storm-induced beach change. Report 1: Empirical foundation and model development. Technical Report, CERC-89-9. 266 p.

Norcross, Z.M., Fletcher, C.H., Merrifield, M., 2002. Annual and interannual changes on a reef-fringed pocket beach: Kailua Bay, Hawaii. Marine Geology, 190, 553-580.

Patsch, K., Griigs, G.B., 2008. A sand budget for the Santa Barbara Littoral Cell, California. Marine Geology, 252, 50-61.

Rosati, J. D., Wise, J.D., Kraus, N.C., Larson, M. (1993). Numerical model for simulating storm-induced beach change. Report 3: User's Manual, Technical Report, CERC-93-2, $65 \mathrm{p}$.

Sedrati, M., 2006. Morphodynamique transversale et longitudinale de plages à barres intertidales en domaine macrotidal et en conditions de forte agitation : Baie de Wissant, Nord de la France. Thèse de Doctorat, Université du Littoral Côte d'Opale, Dunkerque.

Sedrati, M., Anthony, E.J., 2007. Storm-generated morphological change and longshore sand transport in the intertidal zone of a multi-barred macrotidal beach. Marine Geology, 244, 209-229.

Sedrati, M., Anthony, E.J., 2008. Sediment dynamics and morphological change on the upper beach of a multi-barred macrotidal foreshore, and implications for mesoscale shoreline retreat: Wissant Bay, northern France. Zeitschrift für Geomorphologie 52, Suppl. 3, 91 106. 
Sipka, V., 1997. Les cellules sédimentaires du littoral du Nord Pas-de-Calais, Nord de la France. Définition et applications. International Symposium Bordomer 97, Bordeaux, Vol. 1: 61-70.

Thomas, T., Phillips, M.R., Williams, A.T., Jenkins, R.E., 2012. Medium time-scale behaviour of adjacent embayed beaches: Influence of low energy external forcing. Applied Geography, 32, 265-280.

SOGREAH, 2006. Requalification du site de la Baie de Wissant - Réensablement de la partie centrale. Rapport Final, Phase 3, Juillet 2006, 97 p.

van Rijn, L.C., 1993. Principles of Sediment Transport in Rivers, Estuaries and Coastal Seas. Aqua Publications, Delft Hydraulics, Amsterdam, 673 p.

van Rijn, L.C., 2011. Coastal erosion and control. Ocean \& Coastal Management, 54, 867887.

\section{Figure captions}

Figure 1. Wissant Bay in the southern North Sea facing the Dover Strait (a); sketch showing the shoreline status of Wissant Bay and the Line Bank offshore (b).

Figure 2. Offshore wave heights over a one-year period from the Sandettie lightship (UK Met Office) (a), and a two-week record of wind conditions, inshore water levels, wave conditions, and mean longshore and cross-shore currents in the eroding Dune d'Aval sector, January 2005. From Sedrati, 2006.

Figure 3. Rates of shoreline change in Wissant Bay calculated for various time slices between 1949 and 2000, showing the strong fluctuations both alongshore and over time. From Chaverot et al. (2008). The townfront seawall has acted as a rampart against shoreline retreat. Note that longshore transect gaps in top figure are not reproduced in bottom figure.

Figure 4. An 8-year dataset of beach profiles representing the three sectors of the bay: (a) Dune d'Aval, (b) Wissant town front, (c) Dune d'Amont. The data reported here concern monitoring between 1996 and 2005 at intervals of six months. Profile data are missing for the years from 2001 to 2003. The profiles were surveyed using a high-resolution TC 407 Leica total station with errors within $\pm 3 \mathrm{~mm}$ for distance and elevation and $\pm 0.0015^{\circ}$ for direction. An uncertainty margin of $5 \mathrm{~cm}$, covering both field measurement and interpolation errors and uncertainties, was applied in the treatment of the raw profile data. All surveys were referenced to IGN 69 benchmarks of the French national datum.

Figure 5. Profile volume changes over the 8-year survey for the three sectors of the bay: (a) Dune d'Aval, (b) Wissant town front, (c) Dune d'Amont.

Figure 6. Photographs of the seawall fronting Wissant town: (a) 1906; (b) 1952; (c) 1986; (d) 2002; (e) 2007; (f) 2010. The synopsis shows a shift from a situation of relative sand abundance in front of the wall, with sand even masking it $(1952,1986)$, to one of beach erosion and damage to the seawall between 2002 and 2010. Note the rock armouring emplaced to protect the front of the wall in the 2010 photograph.

Figure 7. Sand transport rates calculated using the van Rijn (1993) formula, from data obtained from current meters deployed in January 2005 over two bars submerged at high tide in the eroding Dune d'Aval sector, with peaks expressing the dominant longshore transport (a); the strong relationship between these rates and longshore current velocities (b). From Sedrati (2006). 

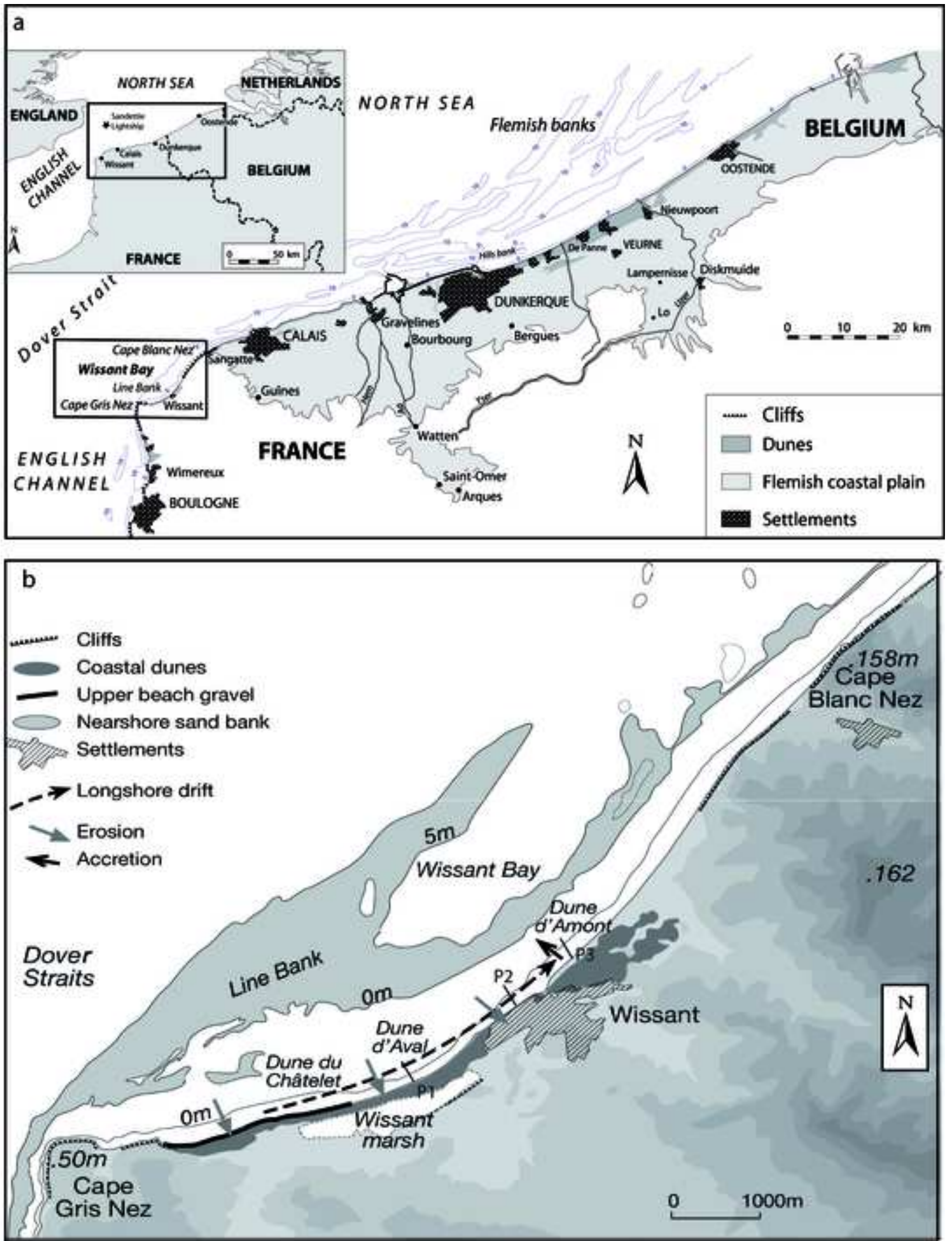

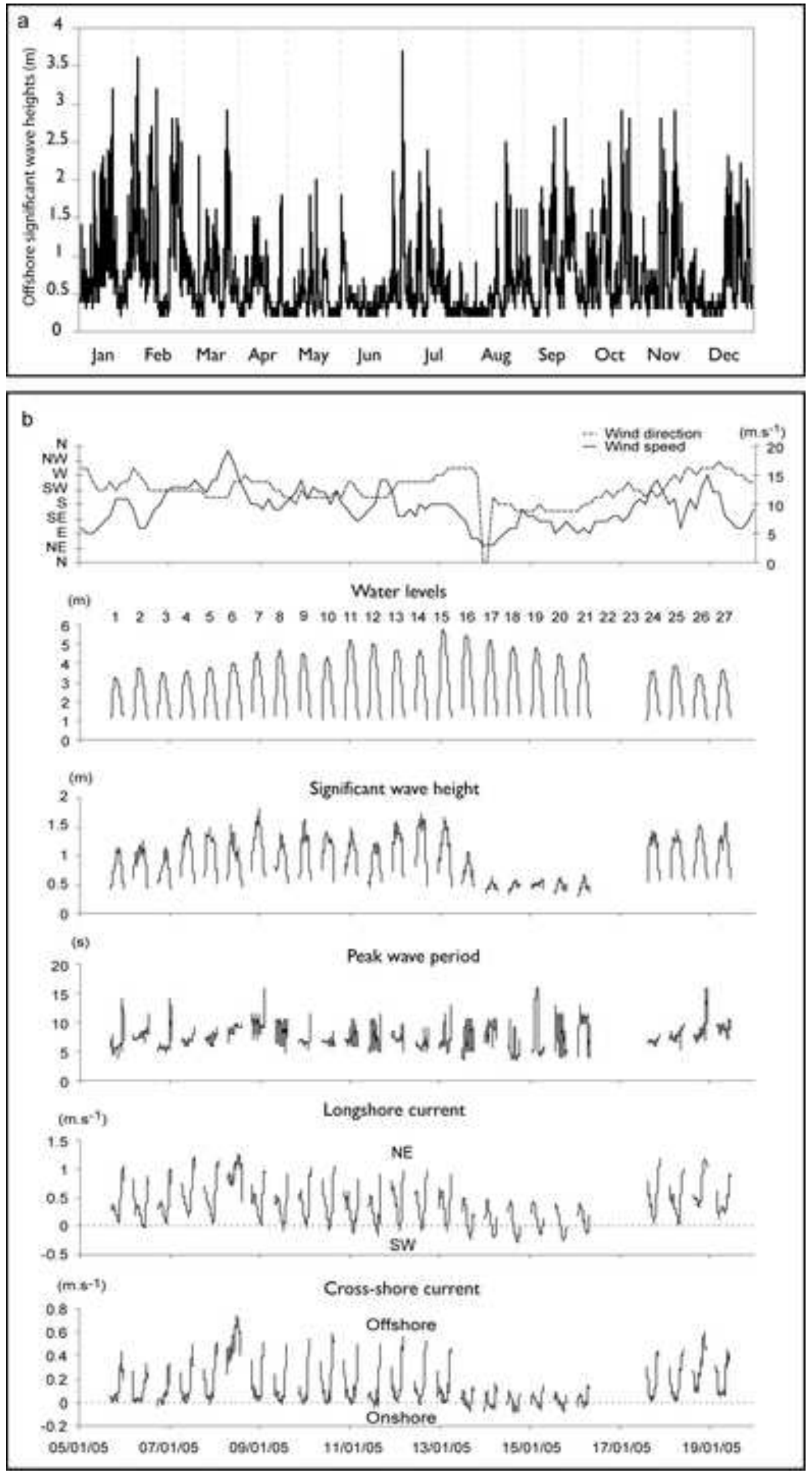

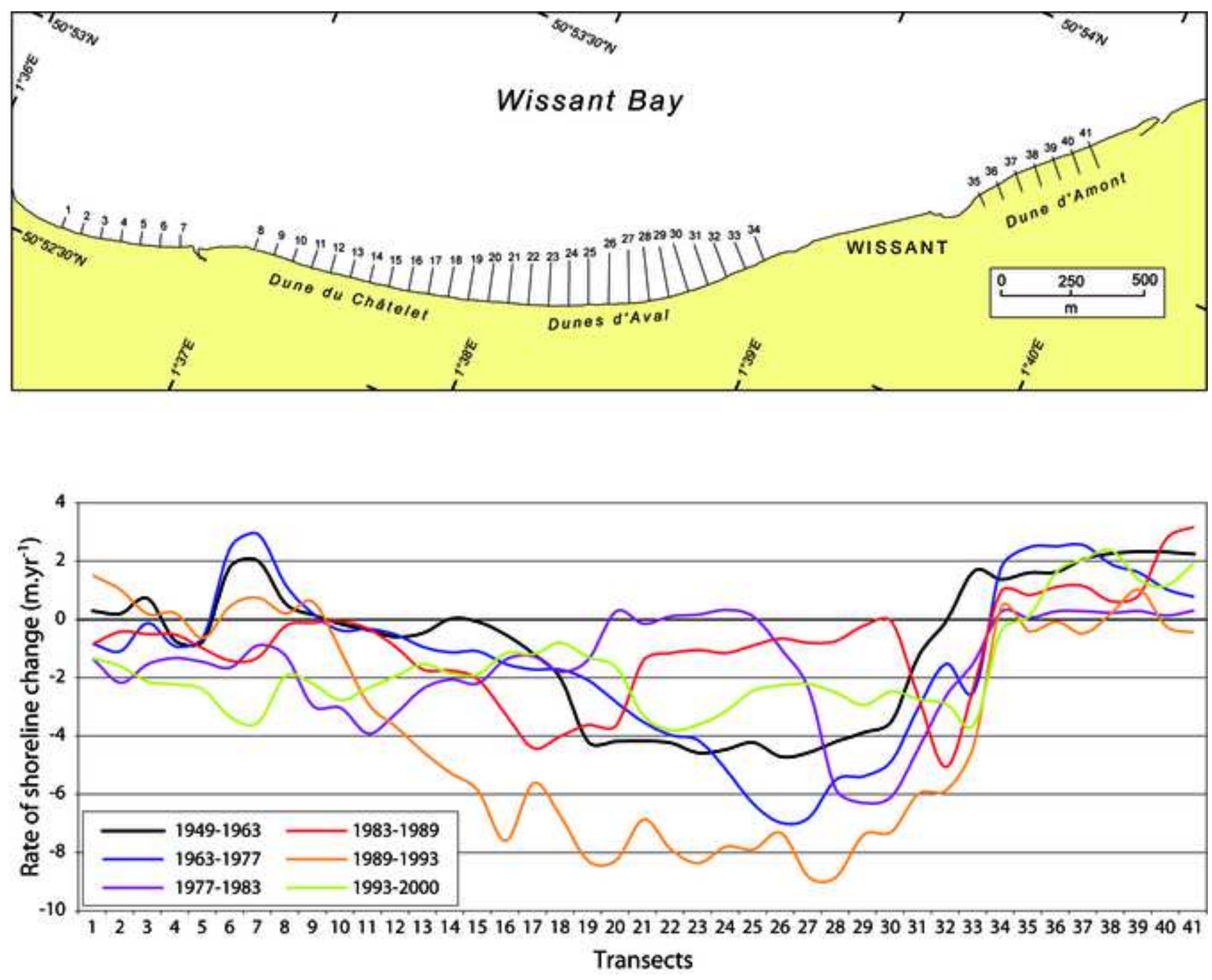

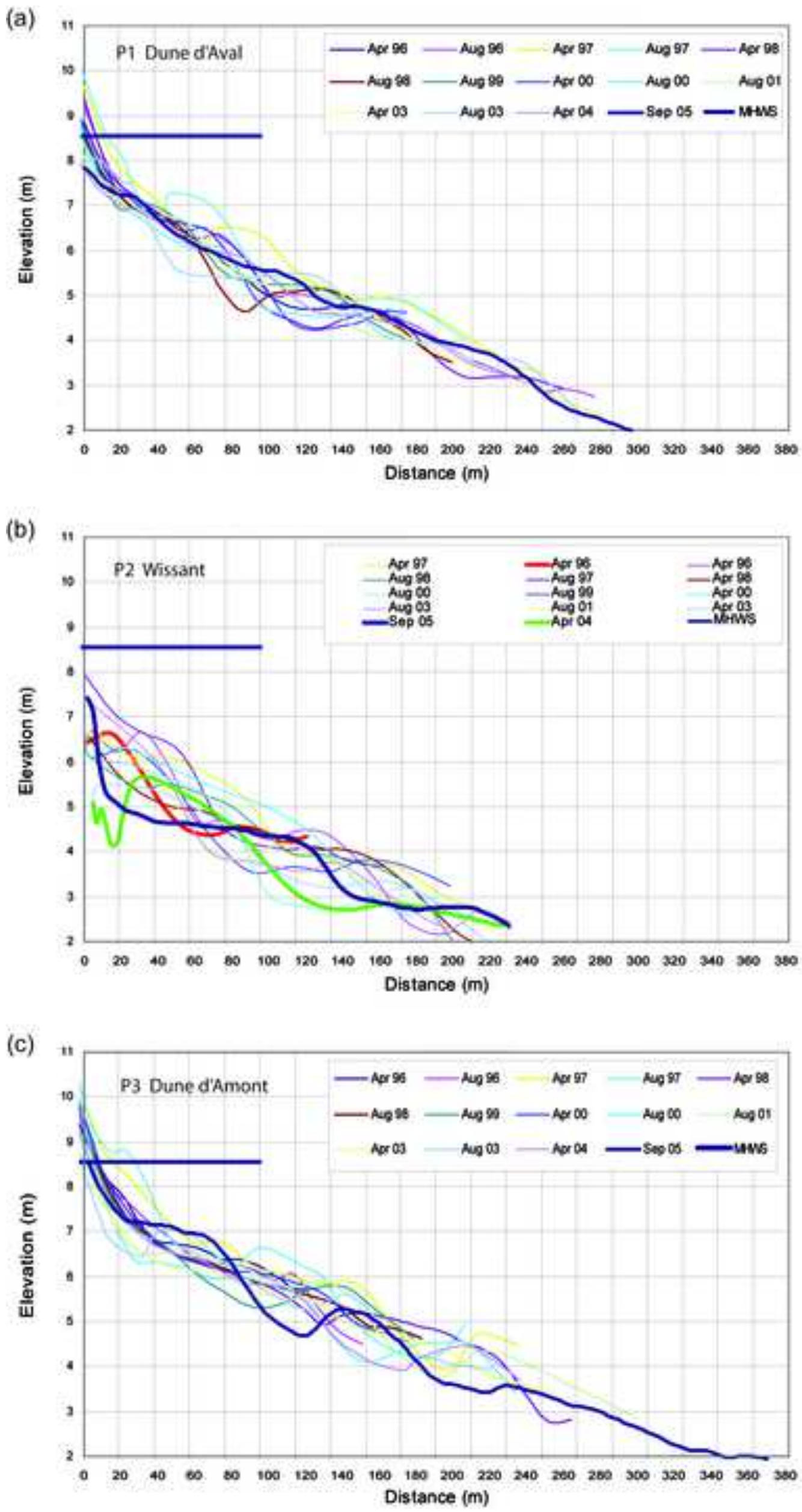
(a)

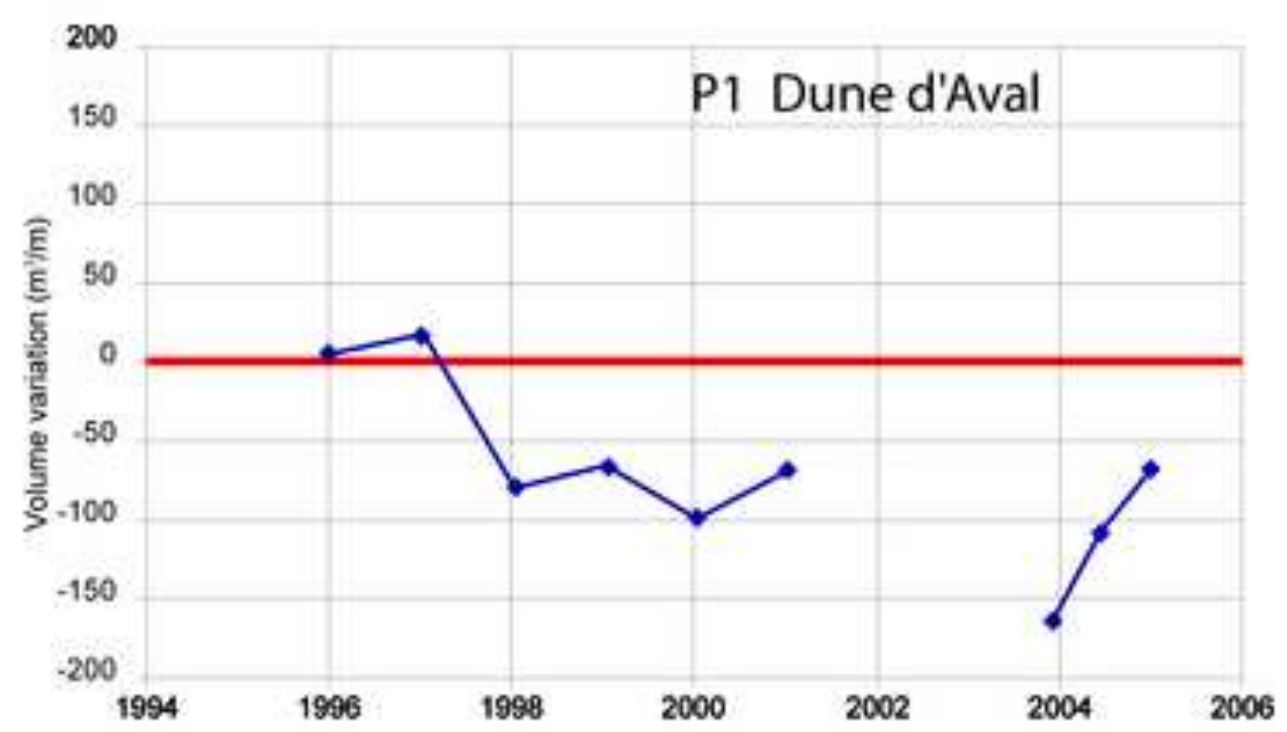

(b) 200

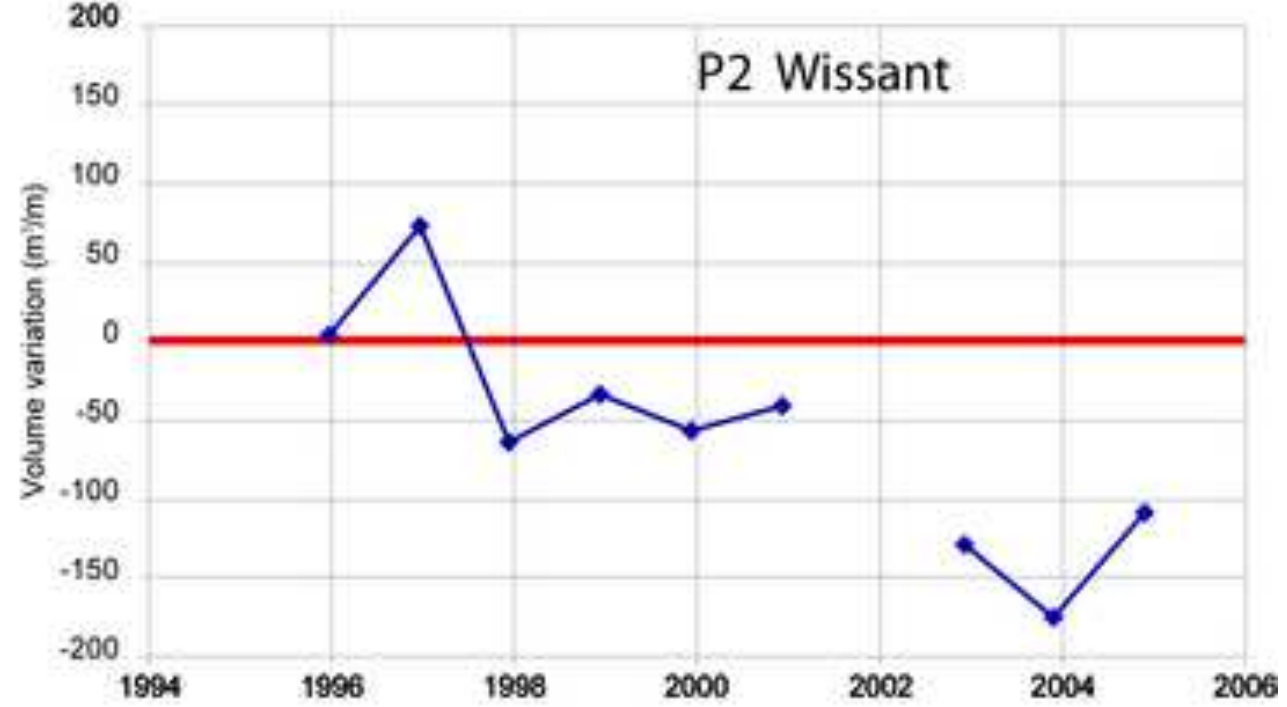

(c)

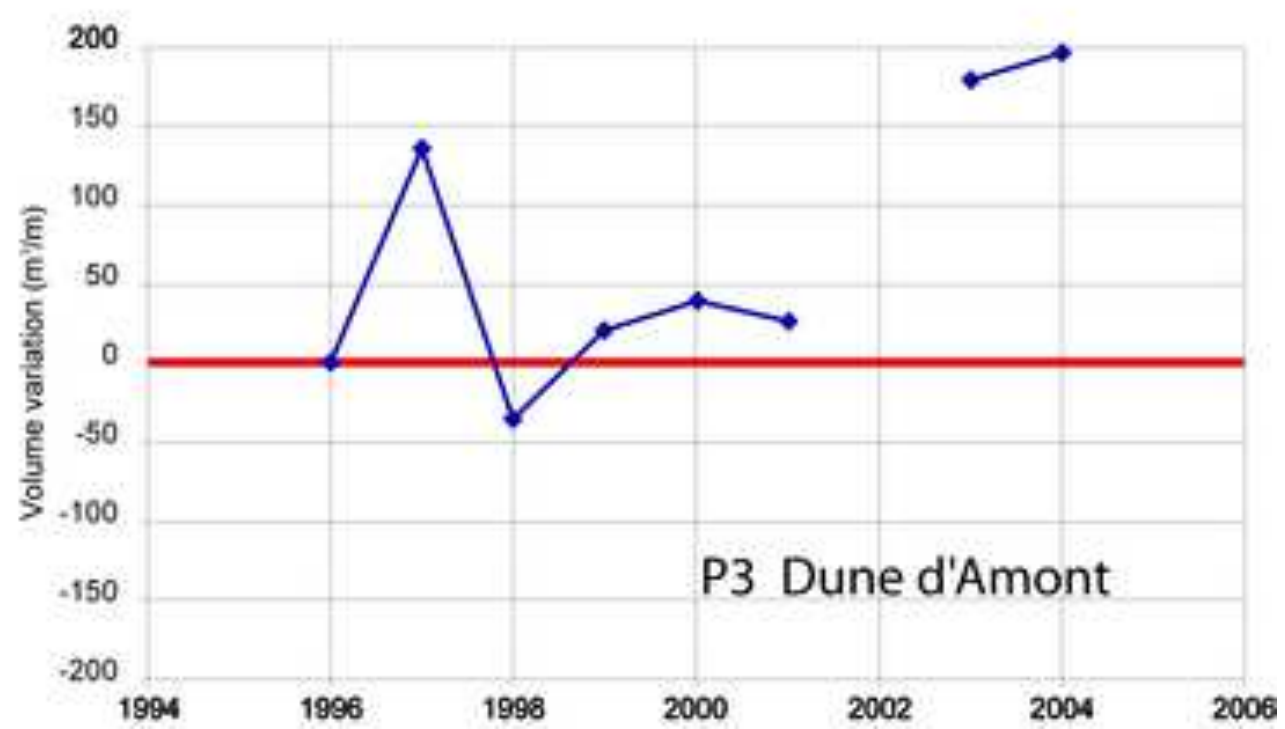




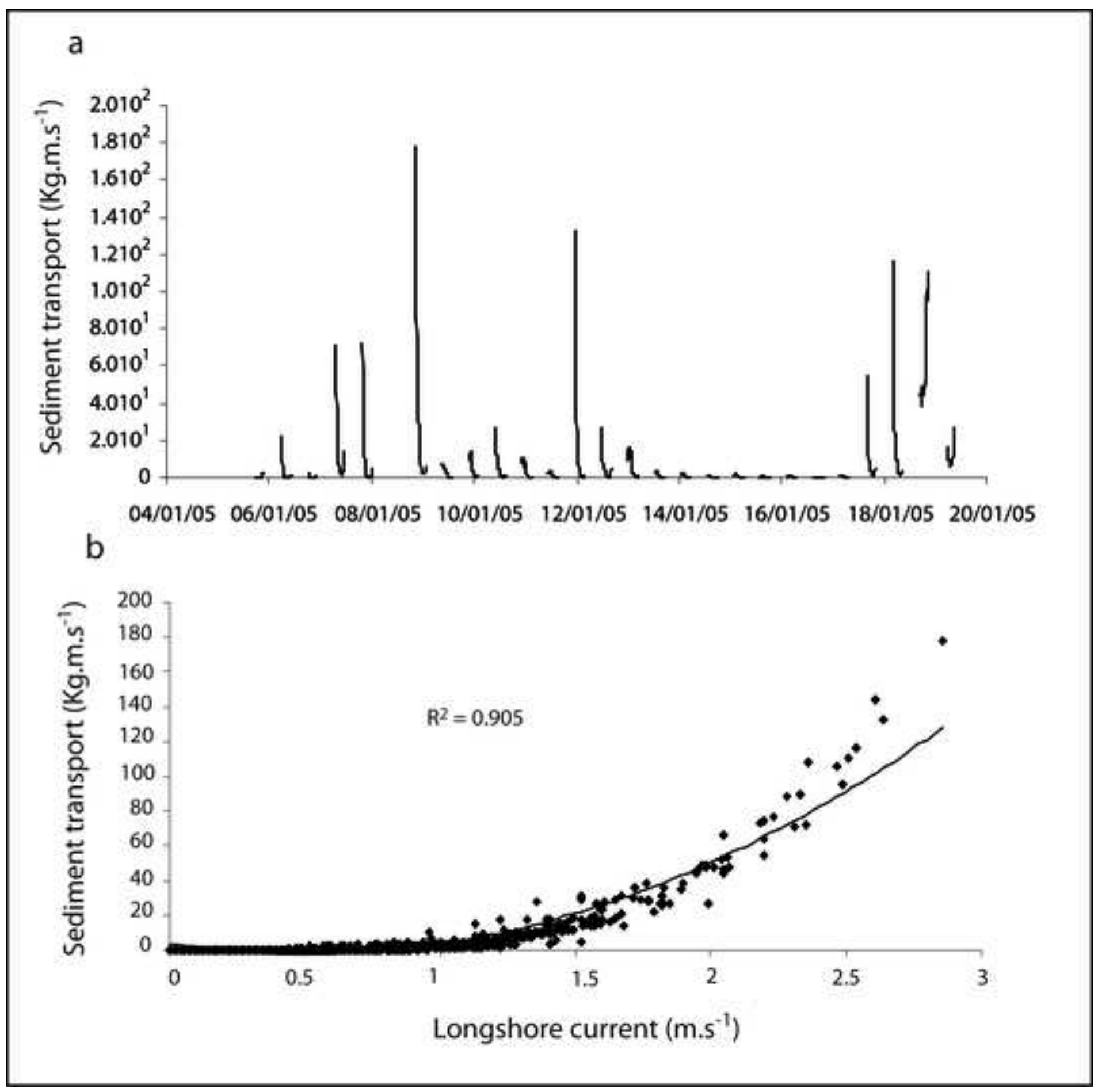

